Japan. J. Med. Sci. Biol., 23, 303-314, 1970

\title{
SEPARATION AND PROPERTIES OF “IN VIVO GROWN TUBERCLE BACILLI" ASSOCIATED WITH THE LYSOSOMAL MEMBRANE
}

\author{
KoomI KANAI AND EIKo KONDO \\ Department of Tuberculosis, National Institute of Health, \\ Shinagawa-ku, Tokyo 141, Japan
}

(Received: September 19th, 1970)

\begin{abstract}
SUMMARY : “ In vivo grown tubercle bacilli " were separated mechanically from infected mouse lungs. The bacilli, unlike the same strain grown in vitro, were hydrophilic. The former were different from the latter by lowered activities of acid phosphatase at $\mathrm{pH} 6.5$ and of tetrazolium-reduction, and also by new activities of acid proteinase and of acid phosphatase functional at much lower $\mathrm{pH}$. Combination of Gomori stain for acid phosphatase at $\mathrm{pH} 5.0$ and Ziehl-Neelsen stain revealed the association of the in vivo bacilli with membraneous tissue components with Gomori-positive reaction prolucts and some of the bacilli themselves stained black. Such observations were never obtained with in vitro grown bacilli. When the in vitro grown bacilli were incubated with lysosomal components separated from the mouse tissue, the surface of the bacilli showed a strong affinity to the lysosomal components, and in vitro tests demonstrated that the enzymatic activities of the bacilli changed into the pattern of the in vivo bacilli. The water-soluble peptide fraction and the free fatty acid fraction of the lysosomal components were found responsible for lowering the activities of tetrazolium-reduction and acid phosphatase specific for the bacilli.
\end{abstract}

\section{INTRODUCTION}

In our preceding paper (Kanai and Kondo, 1970), the in vitro experiments suggested that the lysosomal membrane will be the site of interaction between tubercle bacilli and phagocytic cells and play a part in the final stage of defense mechanism. In order to obtain evidences to prove that such interaction actually occurs in vivo, the authors made an attempt to examine the properties of tubercle bacilli grown in the mouse lungs. The basic idea was that they might have some characteristics reflecting the association with the lysosmal membrane during their stay in host cells.

\section{Materials AND Methods}

The materials and methods employed in this investigation were mostly the same as those described in the preceding paper (Kanai and Kondo, 1970). Some additional matters are presented below.

金井興美・近藤塋子（国立予防衛生研究所結核部） 
Separation of in vivo grown tubercle bacilli from infected mouse lungs: The method was basically identical to that reported by Segal and Bloch (1956) and Artman and Bekierkunst (1961), though some modifications were made. Mice of dd strain were infected intravenously with 0.5 or $1 \mathrm{mg}$ of Mycobacterium bovis (Ravenel). Most of the animals died in 3 to 4 weeks after infection. The lungs enlarged with numerous tubercles to around $1 \mathrm{~g}$ were removed and stored at $-20 \mathrm{C}$. The collected lungs (e. g. $165 \mathrm{~g}$ ) were homogenized in $660 \mathrm{ml}$ of distilled water by a Waring blender under cooling. The homogenate was passed through 3 sheets of gauze and the filtrate was centrifuged at $2,000 \mathrm{rpm}$ for $20 \mathrm{~min}$. The supernatant fluid was discarded and the sediment containing tissue elements and tubercle bacilli was resuspended in $330 \mathrm{ml}$ of distilled water and centrifuged at $1,000 \mathrm{rpm}$ for $5 \mathrm{~min}$. The resulting supernatant was decanted and saved, and centrifuged again at 2,000 rpm for $15 \mathrm{~min}$. The sediment was then treated with $1 \mathrm{M} \mathrm{NaCl}$ to dissolve contaminating nuclear fragments originating from host cells, and centrifuged at 3,000 rpm for $10 \mathrm{~min}$. This step was repeated until the supernatant was no more viscous. Finally, the sediment was washed by centrifugation with distilled water 2 to 3 times. The grey-white sediment was a mass of "in vivo grown tubercle bacilli" and Ziehl-Neelsen stain could confirm the presence of acid-fast bacilli and the absence of non-acid-fast components. For further purification, trypsin-digestion (200 $\mu \mathrm{g}$ per $\mathrm{ml}$ of $1 / 15 \mathrm{M}$ phosphate buffer of $\mathrm{pH}$ 8.0) was made at $37 \mathrm{C}$ for $3 \mathrm{hr}$.

Staining procedure (combination of Gomori and Ziehl-Neelsen stains): The basic principle was reported by Hart and Young (1969). Bacillary material was suspended in $1.8 \mathrm{ml}$ of $0.1 \mathrm{M}$ acetate buffer of $\mathrm{pH} 5.0$ containing lead nitrate in $0.12 \%$. The suspension was combined with $0.2 \mathrm{ml}$ of $3 \%$ sodium $\beta$-glycerophosphate and also with $0.2 \mathrm{ml}$ of $0.05 \%$ Tween 80 . The mixture was incubated at $37 \mathrm{C}$ for 3 to $5 \mathrm{hr}$. This was smeared on a slide, air-dried and fixed by gentle heating. Sometimes, the reaction procedure was conducted after fixation with glutaraldehyde. After repeated swilling with $0.05 \mathrm{M}$ acetate buffer of $\mathrm{pH} 5.0$ and then with distilled water, the smear was treated with diluted ammonium sulfide solution for a few minutes and rinsed with distilled water. After drying, stain was conducted using steaming carbol fuchsin for $7 \mathrm{~min}$, being followed by decolorization with $1 \% \mathrm{HCl}$ alcohol. Then, the slide was retreated by diluted ammonium sulfide solution. The smear was rinsed with water, and, if needed, counter-stained finally with aqueous methylene blue. When tissue cells were the material to be stained, Gomori-reagent was used in the environment of physiological saline solution and the incubation period was 30 to $60 \mathrm{~min}$.

Chemical separation of host components associating with "in vivo bacilli": The sample was digested with $200 \mu \mathrm{g}$ trypsin per $\mathrm{ml}$ of $\mathrm{M} / 15$ phosphate buffer of $\mathrm{pH} 8.0$ for $1 \mathrm{hr}$ at $37 \mathrm{C}$. The digested material was washed 3 times by centrifugation with distilled water, and then extracted with $90 \%$ acetone. The extract was fractionated by the method described in the previous paper (Kanai and Kondo, 1970) to obtain hydrophobic proteins, phospholipid fraction, neutral fat fraction, free fatty acid fraction and water-soluble peptide fraction.

Examination for enzymatic activities: Acid phosphatase activity-Activity was determined using $0.5 \%$ p-nitrophenyl phosphate as substrate and $0.1 \mathrm{M}$ acetate buffer ranging in $\mathrm{pH}$ from 3.5 to 6.2 , and also maleic acid buffer of $\mathrm{pH} 6.5$. The 
reaction mixture consisted of $0.8 \mathrm{ml}$ of buffer, $0.1 \mathrm{ml}$ substrate solution, $0.1 \mathrm{ml}$ of $100 \mu \mathrm{M}$ EDTA, and $0.1 \mathrm{ml}$ of enzyme sample. The amount of released $\mathrm{p}$ - nitrophenol after incubation at $40 \mathrm{C}$ for a given time was determined by a Coleman spectrophotometer set at $420 \mathrm{~m} \mu$ after alkalinization of the mixture with $2 \mathrm{ml}$ of $0.5 \mathrm{M} \mathrm{NaOH}$. Blank tube was mixed with $\mathrm{NaOH}$ at zero time. When the bacilli were enzyme sample, reading was made after removing them by centrifugation. Cathepsin activity - The assay was done by adding $0.2 \mathrm{ml}$ of enzyme sample to $0.4 \mathrm{ml}$ of a $10 \mathrm{mg}$ per $\mathrm{ml}$ denatured hemoglobin (Nutritional Biochemical Corporation, Cleveland) dissolved in $0.1 \mathrm{M}$ acetate buffer of $\mathrm{pH} 3.19$. Digestive reaction was carried out at $40 \mathrm{C}$ for $90 \mathrm{~min}$ after which $0.6 \mathrm{ml}$ of $5 \%$ trichloracetic acid was added to the mixture. After centrifugation, $0.5 \mathrm{ml}$ of the supernatant was determined for protein amount by Folin test. The amount of nonprecipitating protein reflects the proteolytic activity of the sample. Tetrazolium salt-reducing activity - The test was conducted adding a test sample suspended in $0.8 \mathrm{ml}$ of $0.05 \mathrm{M}$ acetate buffer ( $\mathrm{pH} 5.6$ ) to the mixture of $0.1 \mathrm{ml}$ of $1 \% 2,3,5$, triphenyl tetrazolium chloride (TTC), $0.1 \mathrm{ml}$ of $5 \%$ sodium lactate and $0.05 \mathrm{ml}$ of $1 \mathrm{M}$ phosphate buffer of $\mathrm{pH} 8.0$. The final $\mathrm{pH}$ of the reaction mixture was 7.4 , which was incubated at $37 \mathrm{C}$ for a given time. The reaction was stopped by adding trichloracetic acid to the final $5 \%$ and centrifuged at $3,000 \mathrm{rpm}$ for $10 \mathrm{~min}$. The reddish pellet was extracted using $3 \mathrm{ml}$ of acetone and centrifuged again. The optical density at $500 \mathrm{~m} \mu$ of the supernatant was determined as the amount of reduced TTC.

\section{RESUlTS}

\section{Origin of "In Vivo Grown Bacilli"}

In order to see the origin of " in vivo bacilli" in the infected lungs, some survey was made. Mice were infected intravenously with $1 \mathrm{mg}$ of Ravenel strain. Ten and 20 days later, the lungs were removed and cut into small pieces. They were suspended into $0.85 \% \mathrm{NaCl}$ and gently pressed in a Teflon homogenizer without making a homogenate. The extract was centrifuged at 2,000 rpm for $5 \mathrm{~min}$. Smears were made from the sediment and stained by Giemsa stain, Gomori stain for acid phosphatase at $\mathrm{pH} 5.0$ and by the ZiehlNeelsen method. Most of leucocytes obtained from the infected mouse lungs were macrophages and lymphoid cells. In the smear of the 10 day infection sample, the bacilli were present intracellularly within macrophages (Fig. 1). In some macrophages, the bacilli were numerous enough to appear occupying almost the entire space of the cell (Fig. 2). Fig. 3 shows a broken macrophage out of which the bacilli are multiplying. The bacilli within macrophages were often intermingled with Gomori-positive granules (Fig. 4). In the smear of 20 day infection sample, most of the bacilli were found extracellularly but within the spread of membraneous tissue components. Fig. 5 shows this condition by the combined stain of Gomori and carbol-fuchsin. Attention should be paid to the fact that at this stage of infection some bacilli were stained by weak Gomoripositive reaction. 


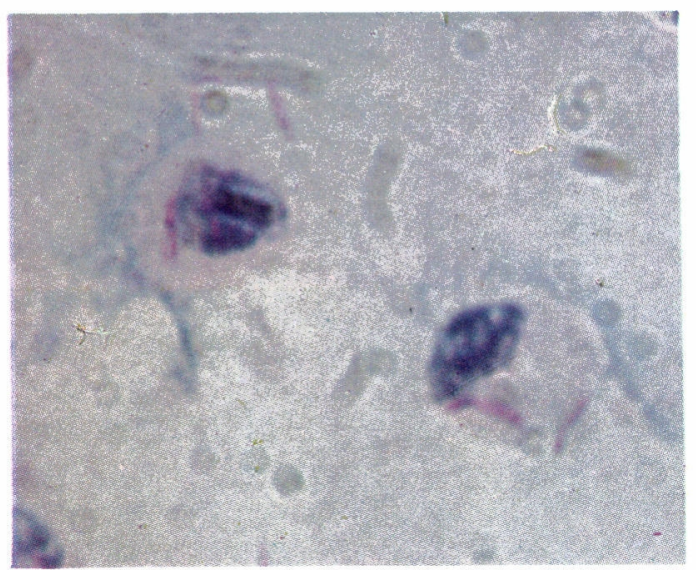

Fig. 1

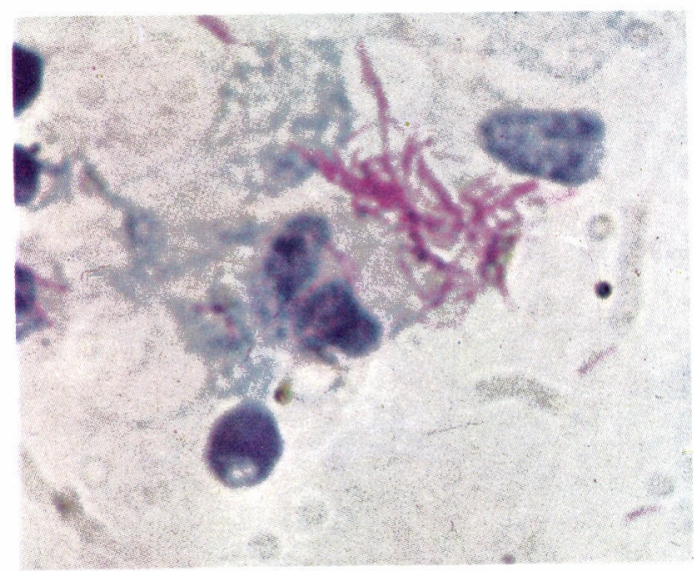

Fig. 3

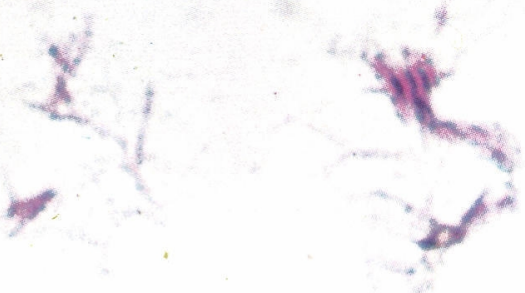

Fig. 5

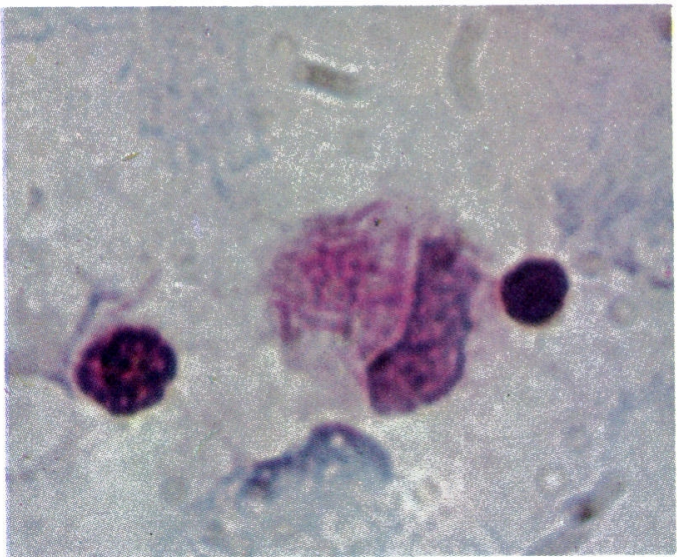

Fig. 2

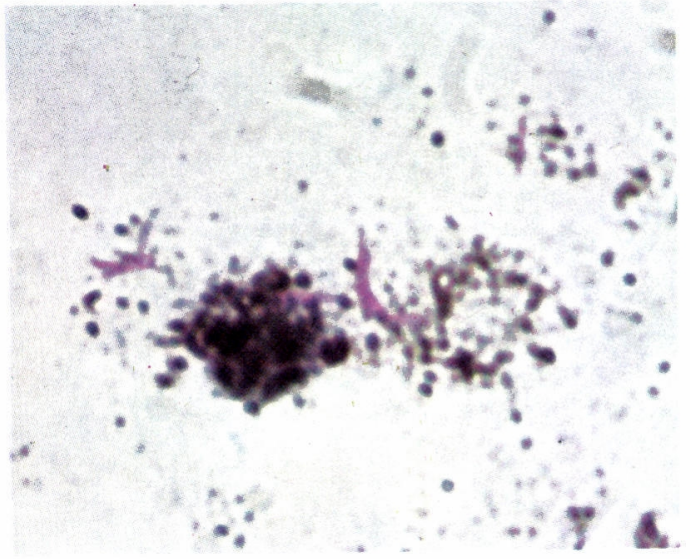

Fig. 4

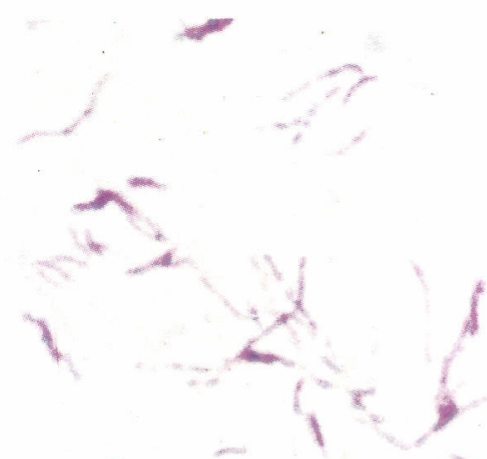

Fig. 6 


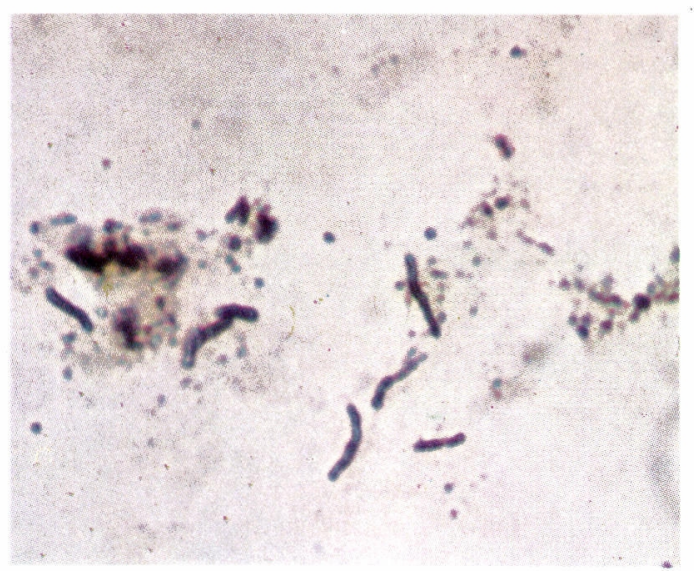

Fig. 7

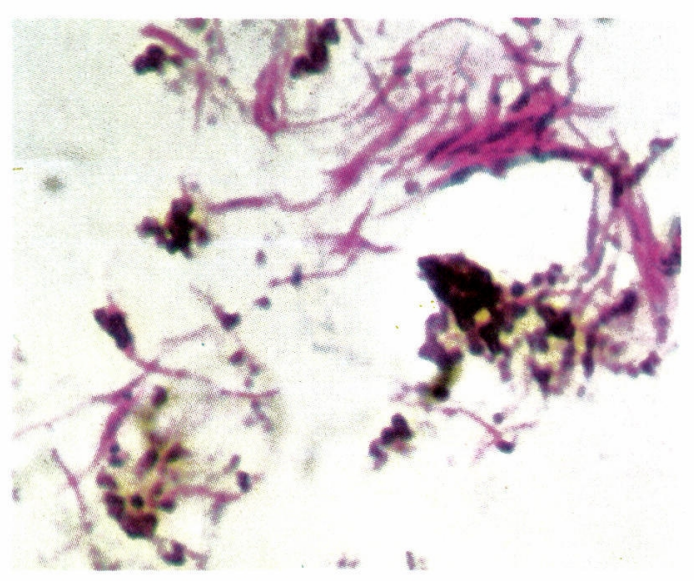

Fig. 9

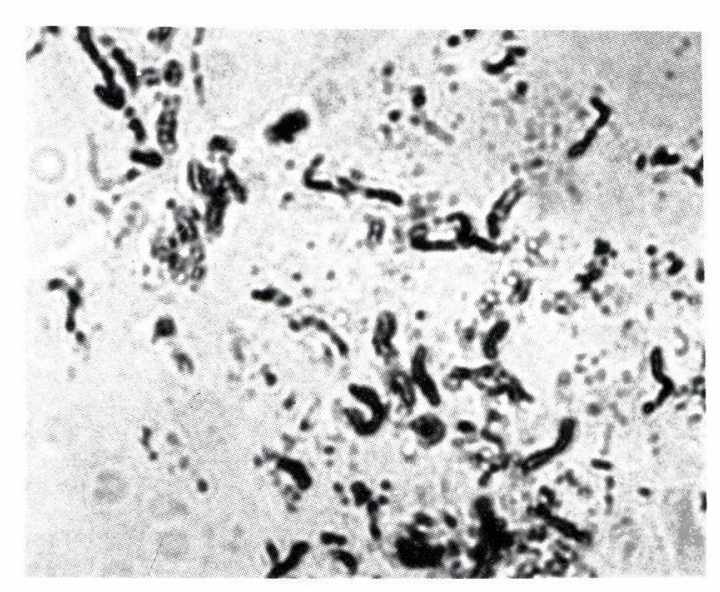

Fig. 11

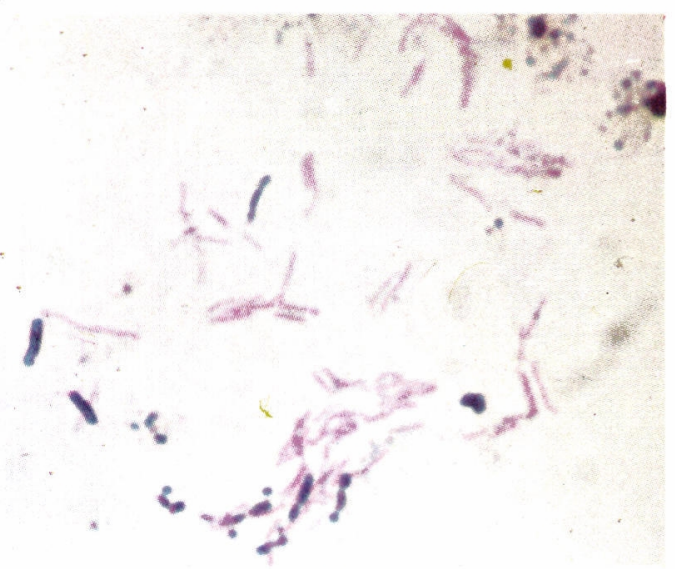

Fig. 8

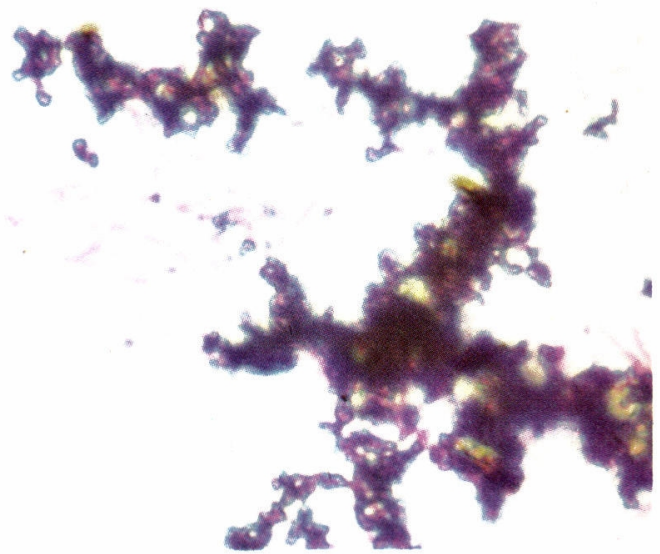

Fig. 10 


\section{EXPLANATION OF FigURES}

(Magnification $\times, 1500)$

Fig. 1. Acid-fast bacilli within alveolar macrophages of the mouse lungs of 10 day infection (Ziehl-Neelsen stain).

Fig. 2. Acid-fast bacilli occupying almost the entire space of a macrophage (Combination of Giemsa and Ziehl-Neelsen stain).

Fig. 3. A broken macrophage with multiplying acid-fast bacilli (Ziehl-Neelsen stain).

Fig. 4. Acid-fast bacilli within the cells having numerous Gomori-positive granules (Combination of Gomori and Ziehl-Neelsen stain).

Fig. 5. Extracellular acid-fast bacilli intermingled with membraneous tissue elements in the lungs of moribund mice, some of which are weakly Gomori-positive at $\mathrm{pH} 5.0$ (Combination of Gomori and carbol fuchsin stain).

Fig. 6. Smear of "in vivo grown tubercle bacilli" separated from the lungs of moribund mice of massive infection (Ziehl-Neelsen stain).

Fig. 7. Smear of the same preparation of the in vivo bacilli showing the presence of Gomori-positive bacilli and their association with tissue elements with Gomori-positive reaction products (Gomori stain at $\mathrm{pH}$ 5.0).

Fig. 8. Smear of the in vivo bacilli showing the mixed population of Gomori-positive and negative bacilli (Combination of Gomori and carbol-fuchsin stain).

Fig. 9, 10. Smear of the incubated mixture of in vitro grown tubercle bacilli and lysosomal components (Fraction A) showing strong affinity of the components (blackstained elements) to the bacilli (Combination of Gomori and carbol-fuchsin stain).

Fig. 11. Smear of the incubated mixture of in vitro grown bacilli with the Triton X-100 extract of lysosomal granules showing black-stained bacillary forms (Gomori stain).

Fig. 12. Smear of in vitro grown $M$. bovis (Ravenel strain) stained by combination of Gomori at pH 5.0 and Ziehl-Neelsen methods; no black-stained bacilli were revealed. 


\section{Properties of In Vivo Grown Tubercle Bacilli}

"In vivo grown tubercle bacilli" were then separated from the mouse lungs (67 g) infected with $M$. bovis (Ravenel strain) by the method described above. Trypsin digestion was not made. The sample was resuspended in distilled water to the same turbidity as that of a $50 \mathrm{mg}$ per $\mathrm{ml}$ suspension of the same strain of bacilli grown on Sauton synthetic liquid medium. Using these thick suspensions, comparison was made on the acid phosphatase activity, acid proteinase activity and TTC-reducing activity. The suspensions were then subjected to serial ten-fold dilution. Using appropriate dilutions, optical density at $420 \mathrm{~m} \mu$, viable counts, staining counts and cytochemical properties were compared between the in vivo and in vitro bacilli. The results are summarized in Table 1 and Figs. 6 to 8 .

The in vivo bacilli were highly hydrophilic unlike the same strain grown in vitro, and easily suspended in water, confirming the observation first reported by Segal and Bloch (1956). When the two suspensions of in vitro and in vivo bacilli were adjusted to almost the same turbidity, they were very near in both the cell count by Ziehl-Neelsen stain and viable count. In fact, the smear had no or very few non-acid-fast elements at least in this staining (Fig. 6). Paradoxically, however, Gomori-stain at $\mathrm{pH} 5.0$ revealed that the suspension of in vivo bacilli contained tissue components spotted with black reaction product and the black-stained bacilli were associated with those tissue components (Fig. 7). Smears of the suspension of in vitro bacilli stained in the same condition never showed such black-stained materials (Fig. 12). Even when the smear had been treated at $\mathrm{pH} 6.5$ the optimal $\mathrm{pH}$ for acid phosphatase activity of $M$. bovis, the in vitro bacilli did not stain black. Combination of Gomori and ZiehlNeelsen stain demonstrated further that the Gomori-positive bacilli occupied a part of the population of in vivo bacilli (Fig. 8). It was certainly a paradoxical finding that the suspension of in vivo bacilli contained tissue components but it had the similar staining and viable counts at nearly the same turbidity as the suspension of in vitro bacilli. An interpretation was that the in vivo bacilli and the tissue components were present in a mutually associated state in the suspension, but not separately, so that the total turbidity would not be an addition of the two components. This explanation will be supported by the cytochemical observation and also by a high resistance of the in vivo bacilli to $90 \%$ acetone-treatment.

Test of enzymatic activities revealed some differences between the two kinds of bacilli. TTC-reducing activity and acid phosphatase activity at $\mathrm{pH} 6.5$ specific for the in vitro bacilli were reduced in the in vivo bacilli. On the other hand, acid phosphatase activity and acid proteinase activity at $\mathrm{pH} 3.5$ were characteristic to the latter bacilli. These new activities were thought to be due to the tissue components associated with the in vivo bacilli in view of the cytochemical finding.

\section{Affinity of Lysosomal Components to Tubercle Bacilli}

To get an information concerning the affinity of lysosomal components to tubercle bacilli, an in vitro model experiment was conducted. Heat-killed 
Table 1. Properties of in vitro and

\begin{tabular}{|c|c|c|c|c|c|}
\hline \multirow{3}{*}{$\begin{array}{l}\text { M. bovis } \\
\text { (Ravenel) } \\
\text { grown }\end{array}$} & \multicolumn{5}{|c|}{ Suspension in water } \\
\hline & \multirow[b]{2}{*}{ Affinity } & \multirow{2}{*}{$\begin{array}{c}\text { OD } \\
420 \mathrm{~m} \mu\end{array}$} & \multirow{2}{*}{$\begin{array}{l}\text { Counts by } \\
\text { staining* }\end{array}$} & \multicolumn{2}{|c|}{ Viable counts $/ \mathrm{ml}$} \\
\hline & & & & Original & $\begin{array}{c}\text { After } 90 \% \\
\text { acetone } \\
\text { treatment }\end{array}$ \\
\hline $\begin{array}{l}\text { On Sauton } \\
\text { medium }\end{array}$ & Hydrophobic & 0.49 & 81 & $30 \times 10^{6}$ & $<1 \times 10^{2}$ \\
\hline $\begin{array}{l}\text { In mouse } \\
\text { lungs }\end{array}$ & Hydrophilic & 0.52 & 72 & $42 \times 10^{6}$ & $8 \times 10^{5}$ \\
\hline
\end{tabular}

* $0.05 \mathrm{ml}$ of the suspension was spread in the area of $1 \times 5 \mathrm{~cm}$ on a slide, and stained by Ziehl-Neelsen method. Average number of acid-fast bacilli (including the flocks) in each visual field was described.

tubercle bacilli (10 mg) were incubated at $37 \mathrm{C}$ with lysosomal components (Fraction A) obtained from normal or BCG-stimulated mouse lungs (Fig. 2 in

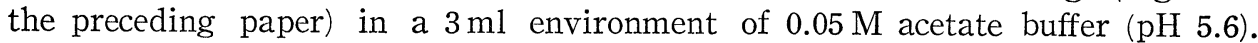
Each mixture was then centrifuged at 2,000 rpn for $10 \mathrm{~min}$ to get sediment. The sediment was washed by centrifugation, using Triton X-100 (0.1\%) the first two

Table 2. Antimycobacterial activity of various fractions separated from a sample of "in vivo grown tubercle bacilli".

\begin{tabular}{|c|c|c|c|c|}
\hline \multirow[b]{2}{*}{ Test material } & \multicolumn{2}{|c|}{ Amt used** } & \multicolumn{2}{|c|}{ Antimycobacterial activity } \\
\hline & $\begin{array}{l}\text { Folin } \\
\text { value* }\end{array}$ & $\begin{array}{l}\text { Weight } \\
\mu \mathrm{g} / \mathrm{ml}\end{array}$ & $\begin{array}{l}\text { Viability by } \\
\text { exposure at } \mathrm{pH} \\
5.6 \text { and } 37 \mathrm{C} \text { for } \\
4 \mathrm{hr} * * *\end{array}$ & $\begin{array}{l}\text { Crowth in } \\
\text { semisynthetic } \\
\text { medium } \\
(\mathrm{pH} 7.0) \\
\end{array}$ \\
\hline $\begin{array}{l}\text { The original sample } \\
\text { of " in vivo bacilli" }\end{array}$ & 108 & & 1.56 & $H$ \\
\hline $90 \%$ acetone extract & 20 & & -1.44 & 一 \\
\hline Phospholid fraction & & 500 & 1.87 & H \\
\hline Neutral fat fraction & & 500 & 1.81 & H \\
\hline Fatty acid fraction & & 50 & -0.66 & - \\
\hline Peptide fraction & 24 & & 0.61 & + \\
\hline $\begin{array}{l}90 \% \text { acetone residue } \\
\text { (hydrophobic proteins) } \\
\text { and bacilli }\end{array}$ & 134 & & 1.92 & H \\
\hline \multicolumn{5}{|l|}{ In vitro grown bacilli } \\
\hline $\int 90 \%$ acetone extract & 19 & & 1.95 & H \\
\hline Fatty acid fraction & & 100 & 1.77 & H \\
\hline $0.05 \mathrm{M}$ acetate buffer $\mathrm{pH} 5.6$ & 0 & & 2.0 & 世 \\
\hline \multicolumn{5}{|c|}{$\begin{array}{l}\text { * } \mu g \text { protein per } \mathrm{ml} \text { by tyrosine-estimation. } \\
\text { T* } \\
\text { The final concentration was } 9 / 10 \text { of the indicated one in the bactericidal } \\
\text { system and } 1 / 5 \text { in the semisynthetic medium of bacteriostatic system. } \\
* * * \log \left(\frac{\text { Viable counts of sample-treated suspension }}{\text { Viable counts of buffer suspension }} \times 100\right)\end{array}$} \\
\hline
\end{tabular}


in vivo grown M.bovis (Ravenel)

\begin{tabular}{cccc}
\hline \multicolumn{4}{c}{ Enzymatic activity } \\
\hline $\begin{array}{c}\text { TTC-reductase } \\
(\text { OD } 500 \mathrm{~m} \mu)\end{array}$ & \begin{tabular}{c} 
Acid \\
proteinase \\
\cline { 3 - 4 }
\end{tabular} & 0 & \multicolumn{2}{c}{ Acid phosphatase at } \\
\hline 0.316 & $0.1900 \mathrm{~m} \mu)$ & 0.035 & $\mathrm{pH} 6.5$ \\
0.024 & 0.19 & 0.67 & 0.48 \\
\hline
\end{tabular}

times and distilled water the next two times. The final sediment was resuspended in $3 \mathrm{ml}$ of distilled water. The $\mathrm{pH}$ activity curve of acid phosphatase reaction was examined of these suspensions. The results are shown in Fig. 13. The figure tells that lysosomal components had an affinity to tubercle bacilli grown in vitro as revealed by the enzymatic activity acquired during such a mixed incubation. This result was confirmed by cytochemical staining (Figs. 9-11).

\section{Antimycobacterial Properties of the Membrane Components Separated from the Sample of In Vivo Bacilli}

Antimycobacterial activities of the chemically separated components were examined as to four aspects; bactericidal activity, bacteriostatic activity, and activities to impair the TTC-reducing property and acid phosphatase activity of in vitro grown tubercle bacilli (Ravene]). As shown in Table 2, the $90 \%$ aqueous acetone extract, the peptide fraction and the free fatty acid fraction were highly active each at the indicated concentrations in killing the bacilli at pH 5.6 buffer environment and also to inhibit growth in semi-synthetic liquid medium of $\mathrm{pH}$ 7.0. The corresponding $90 \%$ acetone extract and the free fatty acid fraction

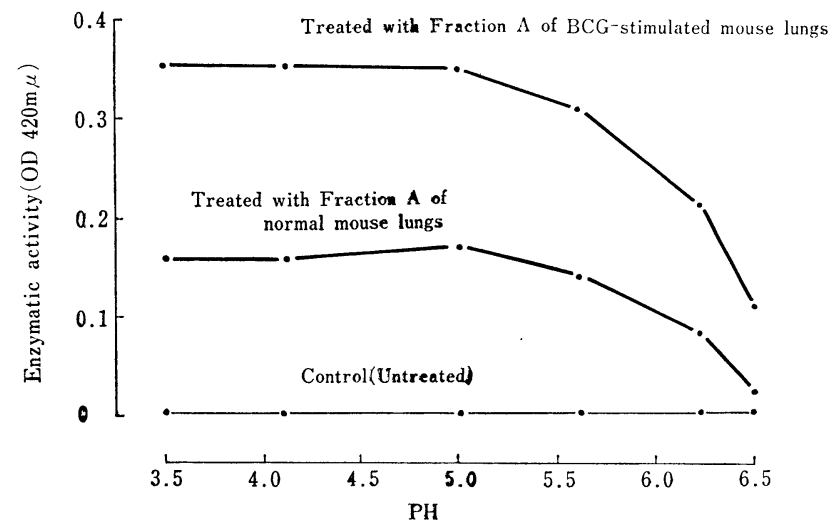

Fig. 13. Afflnity of lysosomal components (Fraction A) to heat-killed tubercle bacilli as indicated by acid phosphatase activity acquired during a mixed incubation. 
Table 3. Effects of various fractions separated from a sample of "in vivo grown tubercle bacilli" upon totrazolium salt-reducing activity of the same strain of tubercle bacilli grown in vitro

\begin{tabular}{|c|c|c|}
\hline \multicolumn{2}{|c|}{$\begin{array}{c}\text { Treatment by exposure at } 37 \mathrm{C} \text { and } \mathrm{pH} 5.6 \\
\text { for } 4 \mathrm{hr} \text { to }\end{array}$} & \multirow{2}{*}{$\begin{array}{l}\text { Enzymatic activity } \\
\text { (OD } 500 \mathrm{~m} \mu \text { of acetone- } \\
\text { extracted formazan) }\end{array}$} \\
\hline Fractions & $\underset{(\mu \mathrm{g} / \mathrm{ml})}{\text { Amt } \text { used }}$ & \\
\hline Fatty acid fraction & $\begin{array}{l}500 \\
100\end{array}$ & $\begin{array}{l}0.012 \\
0.171\end{array}$ \\
\hline Phospholipid fraction & 500 & 0.422 \\
\hline Neutral fat fraction & 500 & 0.287 \\
\hline Peptide fraction & 62 & 0.023 \\
\hline Control & & 0.318 \\
\hline
\end{tabular}

from the Ravenel strain grown on Sauton mediun had no antimycobacterial activity at the similar or even larger concentrations. To examine the properties to inhibit the enzymatic activities of tubercle bacilli, the in vitro grown bacilli of $4 \mathrm{mg}$ per $\mathrm{ml}$ were mixed with the above antimycobacterial components in the $\mathrm{pH} 5.6$ acetate buffer environment for $4 \mathrm{hr}$ at $37 \mathrm{C}$. After the termination incubation, the treated bacilli were subjected to the test of enzymatic activities, using $0.2 \mathrm{ml}$ of the incubated mixture for acid phosphatase activity at $\mathrm{pH} 6.5$ and also $0.8 \mathrm{ml}$ for TTC-reducing activity at $\mathrm{pH} 7.4$. The results are presented in Fig. 14 and Table 3. Here again, the activity of the free fatty acid fraction and the peptide fraction was demonstrated in a clear-cut way.
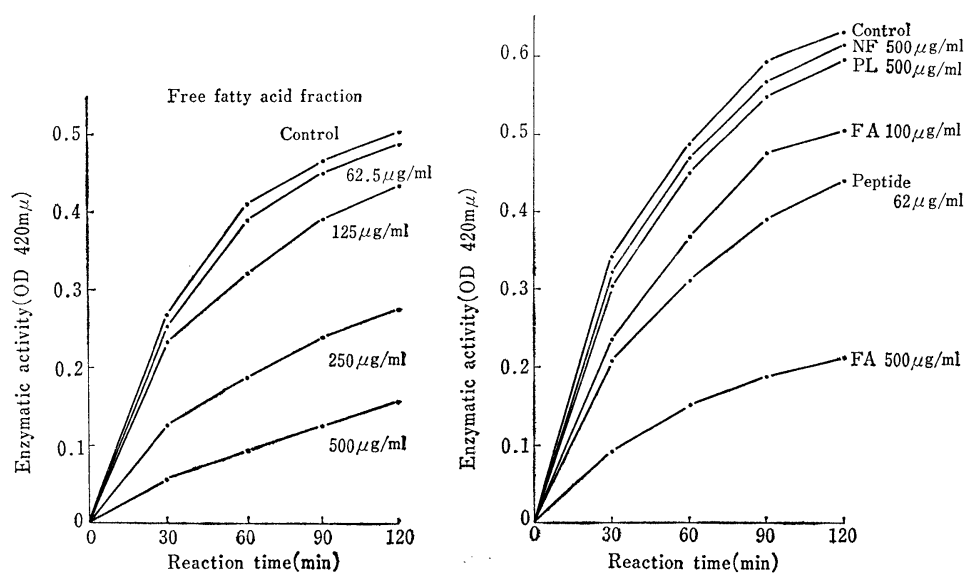

Fig. 14. Effects of various fractions separated from a sample of " in vivo grown tubercle bacilli" upon acid phosphatase activity of the same strain of bacilli grown in vitro.

Note; PL......Phospholipid fraction, NF......Neutral fat fraction, FA......Free fatty acid fraction. 


\section{Discussion}

According to the current understanding of phagocytosis (Hirsch, 1965), ingested bacteria reside in phagocytic vacuole encircled by the invaginated surface membrane, and destroyed within 10 to $15 \mathrm{~min}$ (Rowley, 1962), possibly by the action of hydrolytic enzymes which are shed from lysosomal granules connected to the vacuole. However, such is not always the case with virulent tubercle bacilli. They can not only resist to such digestive mechanisms, but also multiply to a considerable extent in the vacuole. During the stay within such an environment, tubercle bacilli would have some interactions with lysosomal components and the phagolysosomal membrane. In fact, Merckx, Brown and Karlson (1964) observed by an electronmicroscopic study a particular structure ( $\mathrm{X}$ body) in the lungs of mice infected with virulent tubercle bacilli, which they interpreted to be a result of the lysosome-bacillus interaction.

These informations led us to an idea that when tubercle bacilli are separated from infected tissue mechanically they would bear some lysosomal components around their bacillary bodies.

Previous studies on "in vivo tubercle bacilli" have been emphasizing the differences from those grown in vitro; for example, the stainability with Sudan black B (Sheehan and Whitewell, 1949), hydrophilic property, lack of dehydrogenase activity (Segal and Bloch, 1956) (Bekierkunst and Artman, 1960), lack of cytochrome components (Kusaka, Sato and Shoji, 1964), higher virulence and lower immunogenicity (Segal and Bloch, 1957) (Segal, 1965). However, little attention has been paid to a possibility that the in vivo bacilli might be associated with lysosomal components which give the bacilli the properties different from the in vitro ones. Our investigation afforded ample evidences to prove that this actually occurred in vivo. Besides, it was an encouraging observation that the characteristics of the in vivo bacilli were reproduced by a model experiment where the in vitro grown tubercle bacilli were incubated with separated lysosomal components. This means also that an intracellular environment can be produced in vitro to some extent.

The affinity to Sudan black dye has long been regarded as the characteristic property of in vivo grown tubercle bacilli (Sheehan and Whitwell, 1949) (Segal, 1965). This observation can be explained from our results that in vivo tubercle bacilli are coated with lysosomal components, and that lysosomes contain a glycolipid component which can be stained with Sudan black (Allison and Young, 1969). The poor dehydrogenase activity of in vivo tubercle bacilli can be explained by the action of the free fatty acid fraction and the peptide fraction released from the lysosomal components attached to the bacillary surface. Of interest is the fact that the TTC-reducing activity and acid phosphatase activity of tubercle bacilli are those of the membrane system including mesosomes (Yamaguchi, 1968). In this regard, the host-parasite interaction in tuberculous infection will be interpreted as the membrane-membrane interaction between two biological systems. Our further investigation is now under way along this line.

Appreciation is expressed to Mr. K. Fukuda for bis technical assistance in the performance of animal experiments. 


\section{REFERENCES}

Allison, A. C. AND Young, M. R. (1969): Vital staining and fluorescence microscopy of lysosomes. Lysosomes in Biology and Pathology edited by Dingle, J. T. and Fell, H. B., Vol. 2, 600-628, North-Holland Publishing Company, Amsterdam, London.

Artman, A. AND Bekierkunst, A. (1961): Studies on Mycobacterium tuberculosis H37Rv grown in vivo. Am. Rev. Res. Diseases, 83, 100-106.

Bekierkunst, A. AND ARTMAN, M. (1960): Studies on Mycobacterium tuberculosis H37Rv grown in vivo: Inhibitor of lactic acid dehydrogenase in tissues from normal and infected mice. Proc. Soc. Exptl. Biol. Med., 105, 605-609.

HART, D'ARCY P. AND Young, M. R. (1969): Combination of Gomori and Ziehl-Neelsen stains for showing acid phosphatase activity and Mycobacterium tuberculosis in macrophages. Stain Technol., 44, 11-14.

Hirsch, J. G. (1965): Phagocytosis. Ann. Rev. Microbiol., 19, 339-350.

KANAI, K. AND KONDO, E. (1970): Suggested role of the lysosomal membrane as a part of the defence mechanism against tuberculous infection. Japan. J. Med. Sci. Biol., 23, 295-302.

Kusaka, T., SATo, R. AND Shojr. K. (1964): Comparison of cytochromes in mycobacteria grown in vitro and in vivo. J. Bacteriol., 87, 1383-1388.

Merckx, J. J., Brown, A. L. ANd KARLSGN, A. G. (1964): An electronmicroscopic study of experimental infections with acid-fast bacilli. Am. Rev. Resp. Diseases, 89, 485-496.

Rowley, D. (1962): Phagocytosis. Adv. Immunol., 2, 241-264.

SEGAL, W. (1965): Comparative study of in vivo and in vitro grown Mycobacterium tuberculosis. IV. Immunogenic differentiation. Proc. Soc. Exptl. Biol. Med., 118, 214-318.

SEgAL, W. (1965): Comparative study of mycobacterium grown in vivo and in vitro. V. Differences in staining properties. Am. Rev. Resp. Diseases, 91, 285-287.

SEgAL, W. AND BLOCH, H. (1956): Biochemical differentiation of $M$. tuberculosis grown in vivo and in vitro. J. Bacteriol., 72, 132-141.

SEgAL, W. AND BLOCH, H. (1957): Pathologic and immunologic differences of M. tuberculosis grown in vitro and in vivo. Am. Rev. Tuberc., 75, 495-500.

SheEhan, H. L. AND Whitwell, F. (1949): The staining of tubercle bacilli with sudan black B. J. Pathol. Bacteriol., 61, 269-271.

YAMAGUCHI, J. (1968): Electronmicroscopic localization of enzymes in Mycobacterium tuberculosis. Reported in 3rd Annual Tuberculosis Research Conference of U.S.-Japan Cooperative Medical Science Program, Tokyo. 